\title{
Protective Effect of Glutamine on Endothelial Cell ATP in Oxidant Injury ${ }^{1}$
}

\author{
Daniel B. Hinshiaw, M.D., AND Jeanne M. Burger, B.S. \\ Surgical Service, Ann Arbor VA Medical Center, Ann Arbor, Michigan 48105; and the Department of Surgery, \\ University of Michigan, Ann Arbor, Michigan 48109
}

Submitted for publication November 20, 1989

Endothelial cell dysfunction following exposure to $\mathrm{H}_{2} \mathrm{O}_{2}$ is associated with rapid inhibition of glucose-dependent pathways of ATP synthesis. The role other substrates for ATP synthesis (e.g., amino acids) may play in the metabolism of $\mathrm{H}_{2} \mathrm{O}_{2}$-injured cells is unclear. The effect of glutamine, a precursor of the Kreb's cycle intermediate $\alpha$-ketoglutarate on ATP levels in bovine pulmonary artery endothelial cells exposed to $\mathrm{H}_{2} \mathrm{O}_{2}$ was examined. The presence of glutamine during $\mathrm{H}_{2} \mathrm{O}_{2}$ injury significantly enhanced ATP levels in the injured cells. Concentrations of glutamine as low as $50 \mu M$ produced significant improvement of ATP levels in endothelial cells exposed to $5 \mathrm{mM} \mathrm{H} \mathrm{H}_{2} \mathrm{O}_{2}$. The $2 \mathrm{~m} M$ concentration of glutamine produced the greatest benefit, while greater concentrations of glutamine $(5-20 \mathrm{mM})$ were actually associated with progressive decrements of the maximal benefit seen with the $2 \mathrm{~m} M$ concentration. The $2 \mathrm{~m} M$ concentration of glutamine produced similar enhancement of ATP with 1 and $10 \mathrm{mM} \mathrm{H} \mathrm{H}_{2} \mathrm{O}_{2}$ injury as well. Short-term viability following $5 \mathrm{mM} \mathrm{H} \mathrm{H}_{2} \mathrm{O}_{2}$ injury was significantly improved by the presence of $2 \mathrm{~m} M$ glutamine. The most effective concentration of glutamine $(2 \mathrm{mM})$ did not scavenge $\mathrm{H}_{2} \mathrm{O}_{2}$ in a fluorometric assay. These observations suggest that mitochondrial substrates, such as glutamine, that bypass glucose-dependent pathways of ATP synthesis may be useful therapeutic agents for maintenance of ATP levels in oxidant-injured cells. (c) 1990 Academic Press, Inc.

\section{INTRODUCTION}

Hydrogen peroxide $\left(\mathrm{H}_{2} \mathrm{O}_{2}\right)$ has been implicated as one of the major oxidants responsible for cellular injury mediated by polymorphonuclear leukocytes (PMN) during inflammation [1-4]. A number of biochemical events occur in injured cells following exposure to $\mathrm{H}_{2} \mathrm{O}_{2}$. These include DNA strand breakage with activation of the nuclear enzyme poly-(ADP-ribose) polymerase $[5,6]$; activation of

${ }^{1}$ Presented at the Annual Meeting of the Association for Academic Surgery, Louisville, KY, November 15-18, 1989. the glutathione (GSH) redox cycle with oxidation or loss of GSH [7, 8]; loss of intracellular $\mathrm{Ca}^{2+}$ homeostasis [8, 9]; and perhaps most important for short-term cellular survival and function, inhibition of ATP synthesis [10, 11]. Reduction of cellular ATP levels in oxidant injury is followed by disruption of microfilaments, important structural determinants of the cell $[8,12-14]$.

The key glycolytic enzyme, glyceraldehyde 3-phosphate dehydrogenase (GAPDH) is inhibited by $\mathrm{H}_{2} \mathrm{O}_{2}$ and this inhibition accounts for the loss of aerobic and anaerobic glycolytic activity in $\mathrm{H}_{2} \mathrm{O}_{2}$-injured cells $[11,15,16]$. Oxidative phosphorylation of ADP in mitochondria of $\mathrm{H}_{2} \mathrm{O}_{2}$ injured cells is also inhibited but appears to be somewhat less sensitive than glycolysis [11]. In fact, studies with the $\mathrm{P} 388 \mathrm{D}_{1}$ cell line suggest that at intermediate concentrations of $\mathrm{H}_{2} \mathrm{O}_{2}$, ATP synthesis by mitochondrial pathways may be accelerated in response to the $\mathrm{H}_{2} \mathrm{O}_{2}$-mediated inhibition of glycolysis [11].

Although glucose-dependent pathways (aerobic and anaerobic glycolysis) may be inhibited by oxidant injury, it is possible that other substrates, particularly those metabolized via the Kreb's cycle, could serve as sources of energy in cells injured by $\mathrm{H}_{2} \mathrm{O}_{2}$. Branched chain amino acids and glutamine have been demonstrated to be oxidizable sources of energy in isolated perfused organs [17, 18]. In vitro studies have revealed a high level of glutaminase activity in endothelial cells [19]. Glutamine may be metabolized primarily for biosynthetic purposes or catabolized for the generation of ATP depending on the cell and the availability of other substrates [20-22].

It is unclear whether other potentially oxidizable substrates such as glutamine can be used for ATP synthesis in cells injured by oxidants. The purpose of this study was to examine this possibility in a model of $\mathrm{H}_{2} \mathrm{O}_{2}$ injury to endothelial cells.

\section{METHODS}

\section{Cells and Culture}

Bovine pulmonary artery endothelial cells (No. AG 2791A) from the National Institute of Aging, Aging Cell 
Culture Repository (Camden, $\mathrm{NJ}$ ) were grown to confluence in $150-\mathrm{cm}^{2}$ flasks (Corning). Their culture media included RPMI 1640 containing $2 \mathrm{~m} M$ glutamine supplemented with $10 \%$ fetal bovine serum (Whittaker, M. A. Bioproducts), $10 \mathrm{~m} M$ Hepes, $100 \mathrm{u} / \mathrm{ml}$ penicillin, and 100 $\mu \mathrm{g} / \mathrm{ml}$ streptomycin (GIBCO). Cells were passaged after a brief exposure $(10-15 \mathrm{~min})$ to trypsin $(0.05 \%)$ and EDTA (0.02\%; Sigma). Cells from the fifth to the seventh passages were used for these experiments. The cells were suspended at a concentration of $2 \times 10^{6} / \mathrm{ml}$ in modified Gey's buffer (MGB) containing $147 \mathrm{mM} \mathrm{NaCl}, 5 \mathrm{mM} \mathrm{KCl}$, $1.9 \mathrm{mM} \mathrm{KH}_{2} \mathrm{PO}_{4}, 1.1 \mathrm{mM} \mathrm{Na} \mathrm{HPO}_{4}, 0.3 \mathrm{mM} \mathrm{MgSO}_{4}, 1$ $\mathrm{m} M \mathrm{MgCl}_{2}, 5.5 \mathrm{~m} M$ glucose, $10 \mathrm{~m} M$ Hepes, and $1.5 \mathrm{~m} M$ $\mathrm{CaCl}_{2}$. In some experiments, glutamine $(0-20 \mathrm{mM})$ was present in the buffer.

Experiments with suspended cells were carried out at $37^{\circ} \mathrm{C}$ in a shaking water bath.

\section{Cell Viability Measurements}

Cellular viability was estimated at different time points by the ability of the cells to exclude trypan blue [9]. The cells $\left(50 \mu \mathrm{l}\right.$ of $\left.2 \times 10^{6} \mathrm{cells} / \mathrm{ml}\right)$ were incubated briefly with $12 \mu \mathrm{l}$ of $0.1 \%$ trypan blue in $0.9 \% \mathrm{NaCl}$ (final concentration approx $0.02 \%$ ) and the number of cells excluding trypan blue out of 100 cells counted on a hemacytometer was equal to the percentage viable cells.

\section{ATP Determinations}

Endothelial cell ATP levels were assayed by the modified luciferase-luciferin method of Stanley and Williams $[13,23]$. The luciferase-luciferin (Sigma No. LO633) was reconstituted in a buffer containing $1 \%$ bovine serum albumin, $20 \mathrm{~m} M$ glycine, and $2 \mathrm{~m} M$ EDTA, $\mathrm{pH}$ 8.0. Measurements were performed in a LKB Model 1251 automated luminometer. ATP data are expressed as nanomoles $\left(10^{-9}\right.$ mole) ATP per $2 \times 10^{6}$ cells.

\section{$\mathrm{H}_{2} \mathrm{O}_{2}$ Measurements}

Measurement of a range of $\mathrm{H}_{2} \mathrm{O}_{2}$ concentrations in the presence or absence of glutamine was done using a fluorometric assay [24]. The assay is based on the conversion of nonfluorescent para-hydroxyphenyl acetic acid (PHPA) to a fluorescent dimer (PHPA) $)_{2}$ by reaction with $\mathrm{H}_{2} \mathrm{O}_{2}$ in the presence of the enzyme horseradish peroxidase. A cocktail of $166.5 \mu \mathrm{g} / \mathrm{ml} \mathrm{PHPA} \mathrm{(Sigma)} \mathrm{and} 53.4 \mu \mathrm{g} / \mathrm{ml}$ horseradish peroxidase (Sigma) was added to $2 \mathrm{ml}$ of stirred MGB. Small 5- to 10- $\mu$ l aliquots taken from a 2 $\mathrm{m} M$ stock solution of $\mathrm{H}_{2} \mathrm{O}_{2}$ (Fisher) were added and the fluorescence was read in a SLM $8000 \mathrm{C}$ spectrofluorometer at $37^{\circ} \mathrm{C}$ with excitation at $323 \mathrm{~nm}$ and emission at 400 $\mathrm{nm} . \mathrm{H}_{2} \mathrm{O}_{2}$ final concentrations of $0-70 \mu M$ produced near linear increases of (PHPA) $)_{2}$ fluorescence under these conditions.

\section{Statistical Analysis}

Two-way analysis of variance was used for the statistical evaluation of the data unless otherwise indicated.

\section{RESULTS}

\section{Endothelial Cell ATP and $\mathrm{H}_{2} \mathrm{O}_{2}$ Injury-Glutamine Dose Response}

Earlier work with the bovine pulmonary artery endothelial cells [8] demonstrated that injury with a bolus of $5 \mathrm{mM} \mathrm{H}_{2} \mathrm{O}_{2}$ produced significant reduction of endothelial ATP levels and elevation of intracellular $\mathrm{Ca}^{2+}$. Since this was the lowest dose of $\mathrm{H}_{2} \mathrm{O}_{2}$ tested which affected both parameters of endothelial injury, it was chosen to study the effect of a range of glutamine concentrations $(0-20$ $\mathrm{mM}$ ) on ATP synthesis during $\mathrm{H}_{2} \mathrm{O}_{2}$ injury. The endothelial cells were incubated in MGB containing $5.5 \mathrm{mM}$ glucose and the different concentrations of glutamine for 20 min at $37^{\circ} \mathrm{C}$ prior to addition of $\mathrm{H}_{2} \mathrm{O}_{2}$ (final concentration, $5 \mathrm{mM}$ ). Figure 1 depicts the dose response of ATP levels in $\mathrm{H}_{2} \mathrm{O}_{2}$-injured endothelial cells to treatment with glutamine. Significant elevation $(P<0.05, t$ test $)$ of ATP levels in the injured cells treated with glutamine was seen as early as 30 min after addition of $\mathrm{H}_{2} \mathrm{O}_{2}$ with concentrations of glutamine $\geqslant 500 \mu \mathrm{M}$. Cell counts done over the time course demonstrated that cell numbers remained constant during the injury. This indicated that reduction of ATP in the injured samples was not due to a loss of cells as a result of the injury. The lowest concentration of glutamine that produced significant doseand time-dependent enhancement of ATP levels in cells injured with $5 \mathrm{mM} \mathrm{H} \mathrm{H}_{2} \mathrm{O}_{2}$ over the 3-hr time course was $50 \mu M(P<0.05)$. The optimal effect was achieved with 1-2 $\mathrm{m} M$ glutamine $(P<0.0001)$. Concentrations of glutamine $>2 \mathrm{~m} M$ were associated with a decreasing beneficial effect on ATP levels. Indeed, there was no significant benefit seen with glutamine concentrations $>5 \mathrm{mM}$.

\section{Glutamine Effects on Endothelial Cell ATP and \\ Viability $-\mathrm{H}_{2} \mathrm{O}_{2}$ Dose Response}

ATP levels were examined in endothelial cells treated with $2 \mathrm{~m} M$ glutamine prior to and during injury with 0 $10 \mathrm{mM} \mathrm{H}_{2} \mathrm{O}_{2}$ (Fig. 2). After $30 \mathrm{~min}$ of injury glutamine maintained ATP in $\mathrm{H}_{2} \mathrm{O}_{2}$-injured cells at a level severalfold higher than the level induced by 5 or $10 \mathrm{mM} \mathrm{H} \mathrm{H}_{2} \mathrm{O}_{2}$ in the absence of glutamine. The effect of glutamine on

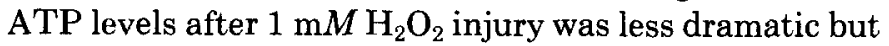
$2 \mathrm{~m} M$ glutamine had a significant effect on ATP levels over the 3 -hr time course at all the $\mathrm{H}_{2} \mathrm{O}_{2}$ concentrations tested $(P<0.05)$. Cells treated with glutamine and exposed to the different concentrations of $\mathrm{H}_{2} \mathrm{O}_{2}$ still had ATP levels significantly lower than those of uninjured control cells $(P<0.0001)$. Glutamine supplementation 

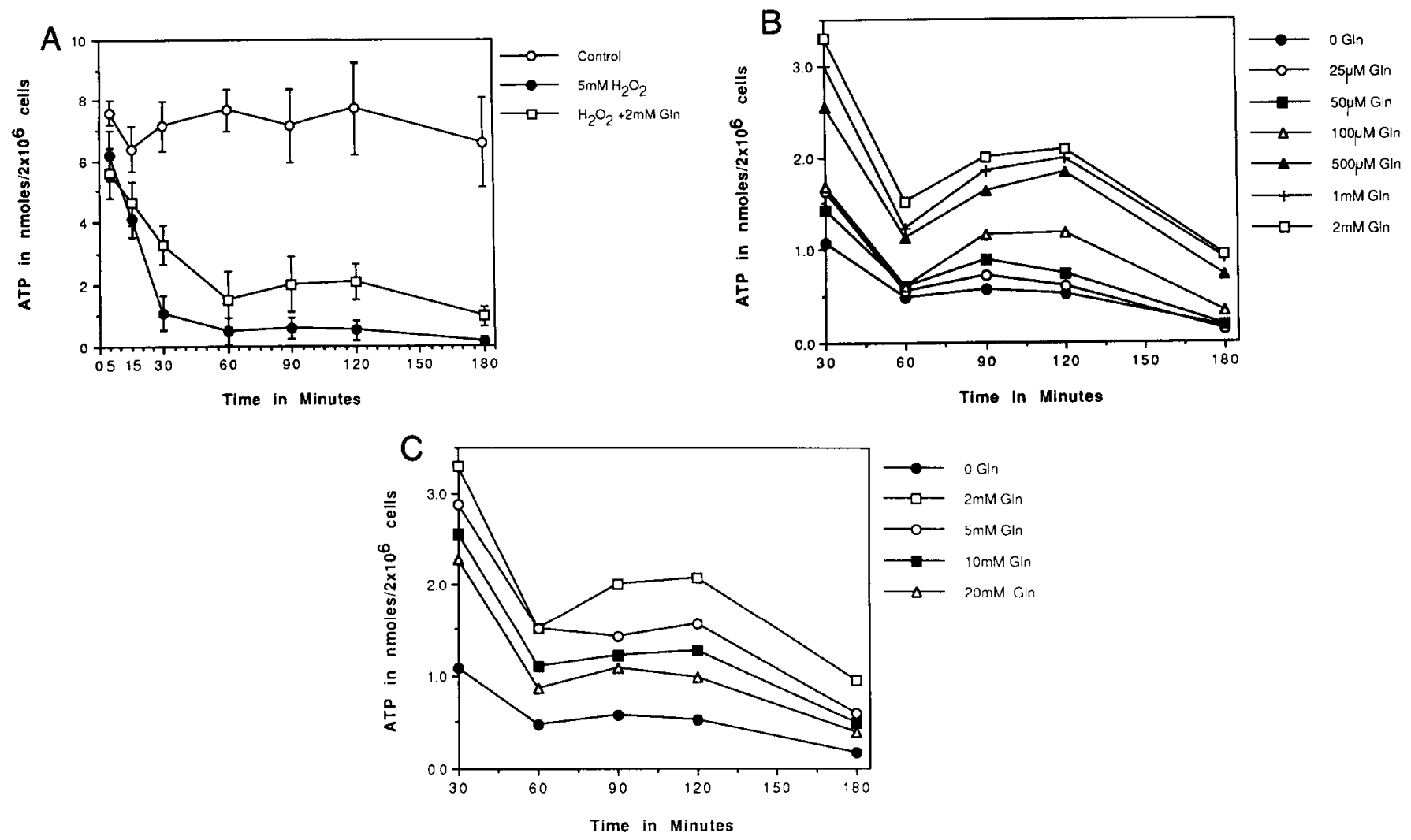

FIG. 1. The effect of glutamine $(0-20 \mathrm{mM})$ on ATP levels in endothelial cells exposed to $5 \mathrm{mM} \mathrm{H}_{2} \mathrm{O}_{2}$. (A) Full time course with $2 \mathrm{mM}$ glutamine. Data points represent the $x \pm \mathrm{SD}$ of four to six separate determinations. (B) 'l'ime course from $30-180$ min after $\mathrm{H}_{2} \mathrm{O}_{2}$ addition with 0-2 $\mathrm{mM}$ glutamine present (expanded scale). SD error bars have been removed for clarity. (C) Time course from 30 to 180 min after $\mathrm{H}_{2} \mathrm{O}_{2}$ addition with 2-20 $\mathrm{m} M$ glutamine present (expanded scale). SD error bars have been removed for clarity.

alone without injury did not significantly enhance ATP levels in the control cells.

The parallel effect of glutamine on viability was also examined in the same experiments. Figure 3 depicts the 5 -hr time course of short-term viability seen in $\mathrm{H}_{2} \mathrm{O}_{2}$ injured cells treated with glutamine. Glutamine-mediated effects on trypan blue exclusion in $\mathrm{H}_{2} \mathrm{O}_{2}$-injured cells became apparent later than differences in ATP levels associated with glutamine treatment. Glutamine did significantly enhance viability in uninjured control cells ( $P$

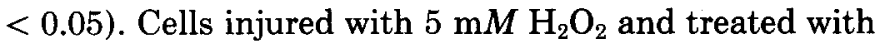
$2 \mathrm{~m} M$ glutamine exhibited significant improvement of
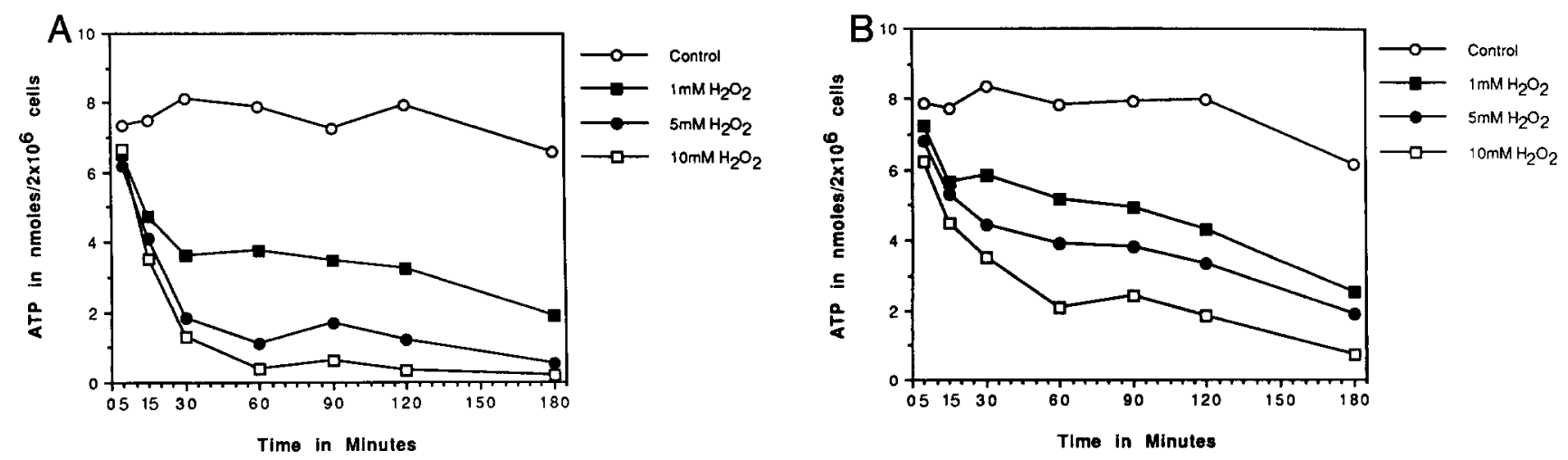

FIG. 2. The effect of $2 \mathrm{mM}$ glutamine on ATP levels in endothelial cells exposed to 0-10 $\mathrm{mM} \mathrm{H}_{2} \mathrm{O}_{2}$. (A) Time course of endothelial ATP levels after addition of $0-10 \mathrm{mM} \mathrm{H} \mathrm{H}_{2} \mathrm{O}_{2}$. (B) Time course of endothelial ATP levels after addition of $0-10 \mathrm{mM} \mathrm{H}_{2} \mathrm{O}_{2}$ in the presence of $2 \mathrm{mM}$ glutamine. Data points represent the $x$ of four to six separate determinations. SD error bars have been deleted for clarity. 

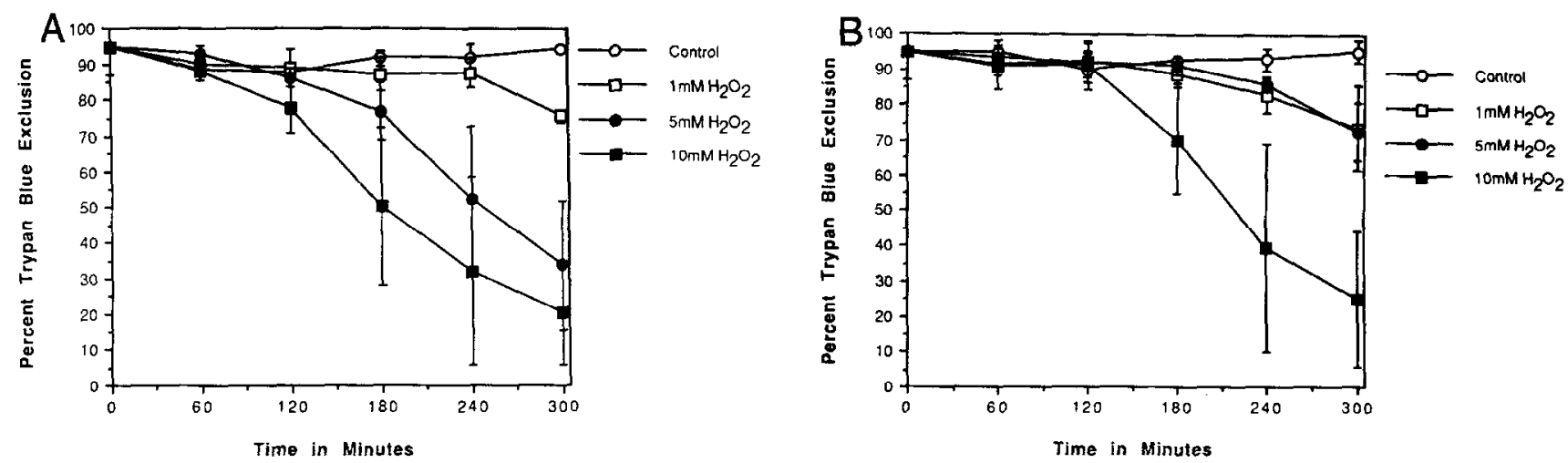

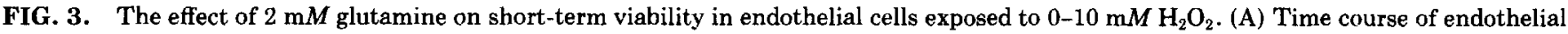
viability (\% trypan blue exclusion) following exposure to $0-10 \mathrm{mM} \mathrm{H}_{2} \mathrm{O}_{2}$. (B) Time course of endothelial viability (\% trypan blue exclusion) following exposure to $0-10 \mathrm{mM} \mathrm{H}_{2} \mathrm{O}_{2}$ in the presence of $2 \mathrm{mM}$ glutamine. Data represent the $x \pm \mathrm{SD}$ of three separate determinations.

short-term viability $(P<0.0001)$. Glutamine did not significantly improve short-term viability in cells injured with 1 or $10 \mathrm{mM} \mathrm{H}_{2} \mathrm{O}_{2}$.

\section{Glutamine and $\mathrm{H}_{2} \mathrm{O}_{2}$}

One possible explanation for the beneficial effect of glutamine on ATP levels and viability in oxidant-injured endothelial cells could be that it may act as a scavenger of $\mathrm{H}_{2} \mathrm{O}_{2}$. To test this hypothesis, standard curves of (PHPA) $)_{2}$ fluorescence (which is directly proportional to $\mathrm{H}_{2} \mathrm{O}_{2}$ concentration) were constructed in the presence of $0-20 \mathrm{~m} M$ glutamine. Glutamine had no significant effect on the reaction of $\mathrm{H}_{2} \mathrm{O}_{2}$ with the fluorometric assay reagents (Fig. 4), except at the $20 \mathrm{mM}$ concentration ( $P$ $<0.001)$. The highest concentration of glutamine did blunt the standard curve of (PHPA $)_{2}$ fluorescence in response to $\mathrm{H}_{2} \mathrm{O}_{2}$.

\section{DISCUSSION}

The presence of glutamine during $\mathrm{H}_{2} \mathrm{O}_{2}$ injury was associated with significantly enhanced endothelial cell ATP levels and short-term viability (at the intermediate concentration of $\mathrm{H}_{2} \mathrm{O}_{2}$ ). The optimal concentration of glutamine was approx $2 \mathrm{mM}$. It is unclear why the higher concentrations of glutamine were associated with no additional benefit and in fact with an apparent adverse effect on ATP levels. A 10-fold increase in glutamine $(20 \mathrm{mM})$ did not alter the $\mathrm{pH}$ of the experimental buffer (data not shown). This tends to mitigate against the possibility that there is a substantially greater $\mathrm{NH}_{3}$ load from the higher glutamine concentrations. It is possible, though, that the additional $\mathrm{NH}_{3}$ load may exert its primary effect on intracellular $\mathrm{pH}$. This will require future experimental confirmation, however.

Glutamine significantly enhanced ATP levels in injured cells at all the concentrations of $\mathrm{H}_{2} \mathrm{O}_{2}$ tested. However, it did not restore ATP in the injured cells to the control range. Short-term viability measured by exclusion of trypan blue was improved to a much greater degree following injury with $5 \mathrm{mM} \mathrm{H} \mathrm{H}_{2} \mathrm{O}_{2}$ than with either 1 or $10 \mathrm{mM}$ $\mathrm{H}_{2} \mathrm{O}_{2}$. This is interesting in light of the effect glutamine had on ATP levels at these concentrations of $\mathrm{H}_{2} \mathrm{O}_{2}$. It is possible that significant differences in viability of gluta-

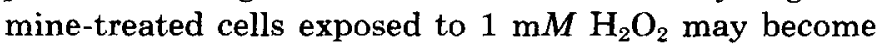
manifest at later time points. Under these experimental conditions it appears that enhancing ATP levels alone may not necessarily enhance short-term viability (e.g., 10 $\mathrm{mM} \mathrm{H}_{2} \mathrm{O}_{2}$ data). From unpublished work in our laboratory it appears that a degree of enhanced short-term viability

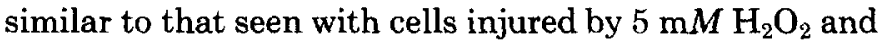
treated with $2 \mathrm{mM}$ glutamine can be achieved following exposure to $10 \mathrm{mM} \mathrm{H} \mathrm{H}_{2} \mathrm{O}_{2}$ if the cells have a media change the day prior to the experiment. The culture media contains $2 \mathrm{~m} M$ glutamine. A limitation of studies of this kind is that the suspended cells have a gradual decline in ATP levels when kept in simple buffers like MGB that contain glucose as the primary substrate. To separate short-term

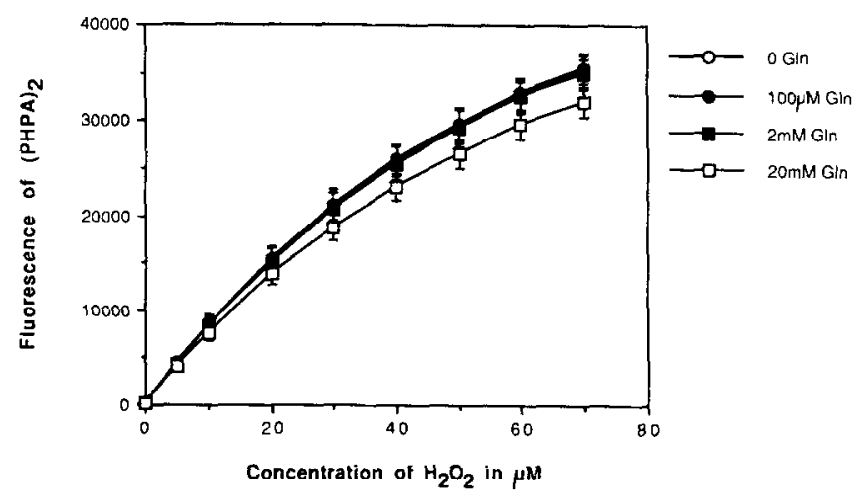

FIG. 4. The effect of glutamine on measurement of $\mathrm{H}_{2} \mathrm{O}_{2}$ by a fluorometric assay. Data represent the $x \pm \mathrm{SD}$ of four separate determinations. 
effects of injury from experimental conditions such as the constituents of the buffer, it will be necessary to repeat these observations with cells kept sterile during injury for later culture so that viability, cell number, ATP levels, etc., may be determined 24-72 hr or longer after growth in culture. It is interesting to note that viability of the control cells over $5 \mathrm{hr}$ in the simple buffer was significantly enhanced by the presence of $2 \mathrm{mM}$ glutamine, although ATP levels were not affected. This observation is consistent with other observations $[20,22]$ regarding glutamine's potential role as a substrate for biosynthetic activitics in cells.

The fluorometric assay for $\mathrm{H}_{2} \mathrm{O}_{2}$ supports the concept that glutamine did not enhance ATP levels and cellular viability by acting as a scavenger of $\mathrm{H}_{2} \mathrm{O}_{2}$. The concentration associated with the greatest benefit, $2 \mathrm{mM}$, had no effect on the measurement of $\mathrm{H}_{2} \mathrm{O}_{2}$ in the fluorometric assay. Although $20 \mathrm{mM}$ glutamine did affect the measurements, this was a concentration associated with a substantially decreased beneficial effect on ATP levels compared to $2 \mathrm{~m} M$ glutamine. Indeed, $20 \mathrm{mM}$ glutamine may interfere with the assay rather than actually scavenge $\mathrm{H}_{2} \mathrm{O}_{2}$. The data do support a role for glutamine as an alternative substrate for ATP synthesis in oxidant-injured cells.

An unanswered question from this data is the longterm effect of glutamine on cellular viability and function. It is quite possible that enhancement of ATP levels in injured cells may only delay the inevitable, particularly if failure of ATP synthesis is not the sine qua non of lethal cell injury.

$\mathrm{H}_{2} \mathrm{O}_{2}$-mediated inhibition of glycolysis by oxidative inactivation of GAPDH occurs rapidly [11]. The data presented here may be interpreted to suggest that mitochondrial ATP synthesis is inhibited more slowly by oxidants than the glycolytic pathway. This would be consistent with gradual loss of overall mitochondrial integrity by diffuse processes (e.g., altered mitochondrial $\mathrm{Ca}^{2+}$ homeostasis) in contrast to specific inhibition of an enzyme(s) in the Kreb's cycle. Glutamine may be a useful tool for further elucidation of the mechanism of injury to mitochondria mediated by oxidants.

A major implication of the effect of glutamine on metabolism in oxidant-injured cells may be in relation to the known loss of glutamine from skeletal muscle following trauma and sepsis [25]. Oxidant-injured cells present in the tissues of a traumatized or septic patient may constitute a potential "sink" for glutamine and help to further drive the protein catabolism in skeletal muscle.

In summary, the presence of glutamine significantly enhanced ATP levels and short-term viability of endothelial cells exposed to $\mathrm{H}_{2} \mathrm{O}_{2}$. These observations may provide new insights into the mechanism of cellular injury mediated by oxidants and may also have therapeutic implications.

\section{ACKNOWLEDGMENTS}

The authors thank Ms. Stacy Wilkin for her secretarial assistance with the manuscript and Dr. Ken Guire, Department of Biostatistics, University of Michigan, for his expert assistance with the statistical evaluation of the data. This work was supported by a Department of Veterans Affairs Merit Review and a grant from Lilly Research Laboratories, Indianapolis, Indiana.

\section{REFERENCES}

1. Simon, R. H., Scoggin, C. H., and Patterson, D. Hydrogen peroxide causes the fatal injury to human fibroblasts exposed to oxygen radicals. J. Biol. Chem. 256(14): 7181, 1981.

2. Weiss, S. J., Young, J., LoBuglio, A. F., Slivka, A., and Nimeh, N. H. Role of hydrogen peroxide in neutrophil-mediated destruction of cultured endothelial cells. J. Clin. Invest. 68: 714, 1981.

3. Nathan, C. F., Silverstein, S. L., Breckner, L. H., and Cohn, Z. A. Extracellular cytolysis by activated macrophages and granuloctyes. II. Hydrogen peroxide as a mediator of cytotoxicity. J. Exp. Med. 149: 100, 1979.

4. Martin, W. J., II. Neutrophils kill pulmonary endothelial cells by a hydrogen peroxide dependent pathway. Amer. Rev. Respir. Dis. 130: 209, 1984.

5. Schraufstatter, I. U., Hinshaw, D. B., Hyslop, P. A., Spragg, R. G., and Cochrane, C. G. Oxidant injury of cells: DNA strand breaks activate poly-(ADP-ribose) polymerase and lead to depletion of nicotinamide adenine dinucleotide. J. Clin. Invest. 77: 1312, 1986.

6. Schraufstatter, I. U., Hyslop, P. A., Hinshaw, D. B., Spragg, R. G., Sklar, L. A., and Cochrane, C. G. Hydrogen peroxide-induced injury of cells and its prevention by inhibitors of poly-(ADP-ribose) polymerase. Proc. Natl. Acad. Sci. USA 83: 4908, 1986.

7. Schraufstatter, I. U., Hinshaw, D. B., Hyslop, P. A., Spragg, R. G., and Cochrane, C. G. Glutathione cycle activity and pyridine nucleotide levels in oxidant-induced injury of cells. J. Clin. Invest. 76: $1131,1985$.

8. Hinshaw, D. B., Burger, J. M., Armstrong, B. C., and Hyslop, P. A. Mechanism of endothelial cell shape change in oxidant injury. J. Surg. Res. 46: 339, 1989.

9. Hyslop, P. A., Hinshaw, D. B., Schraufstatter, I. U., Sklar, L. A., Spragg, R. G., and Cochrane, C. G. Intracellular calcium homeostasis during hydrogen peroxide injury to cultured $\mathrm{P}^{3} 88 \mathrm{D}_{1}$ cells. J. Cell. Physiol. 129: 356, 1986.

10. Spragg, R. G., Hinshaw, D. B., Hyslop, P. A., Schraufstatter, I. U., and Cochrane, C. G. Alterations in adenosine triphosphate and energy charge in cultured endothelial and $\mathrm{P}_{388 \mathrm{D}_{1}}$ cells following oxidant injury. J. Clin. Invest. 76: 1471, 1985.

11. Hyslop, P. A., Hinshaw, D. B., Halsey, W. A., Jr., Schraufstatter, I. U., Sauerheber, R. D., Spragg, R. G., Jackson, J. H., and Cochrane, C. G. Mechanisms of oxidant-mediated cell injury: The glycolytic and mitochondrial pathways of ADP phosphorylation are major intracellular targets inactivated by hydrogen peroxide. J. Biol. Chem. 263: 1665, 1988.

12. Hinshaw, D. B., Sklar, L. A., Bohl, B., Schraufstatter, I. U., Hyslop, P. A., Rossi, M. W., Spragg, R. G., and Cochrane, C. G. Cytoskeletal and morphological impact of cellular oxidant injury. Amer. J. Pathol. 123: 454, 1986.

13. Hinshaw, D. B., Armstrong, B. C., Burger, J. M., Beals, T. F., and Hyslop, P. A. ATP and microfilaments in cellular oxidant injury. Amer. J. Pathol. 132: 479, 1988.

14. Hinshaw, D. B., Armstrong, B. C., Beals, T. F., and Hyslop, P. A. A cellular model of endothelial cell ischemia. J. Surg. Res. 44:527, 1988. 
15. Brodie, A. E., and Reed, D. J. Reversible oxidation of glyceraldehyde 3-phosphate dehydrogenase thiols in human lung carcinoma cells by hydrogen peroxide. Biochem. Biophys. Res. Commun. 148: 120, 1987.

16. Baker, M. S., Feigan, J., and Lowther, D. A. The mechanism of chondrocyte hydrogen peroxide damage. Depletion of intracellular ATP due to suppression of glycolysis caused by oxidation of glyceraldehyde 3-phosphate dehydrogenase. J. Kheumatol. 16: 7, 1989.

17. Windmueller, H. G., and Spaeth, A. E. Uptake and metabolism of plasma glutamine by the small intestine. J. Biol. Chem. 249: 5070, 1974.

18. Schwalb, H., Izhar, U., Yaroslavsky, E., Borman, J. B., and Uretzky, $G$. The effect of amino acids on the ischemic heart. Improvement of oxygenated crystalloid cardinplegic solution by an enriched branched chain amino acid formulation. J. Thorac. Cardiovasc. Surg. 98: 551, 1989.

19. Leighton, B., Cari, R., Hussein, A., and Newsholme, E. A. Maximum activities of some key enzymes of glycolysis, glutaminolysis, Krebs cycle and fatty acid utilization in bovine pulmonary endothelial cells. FEBS Lett. 225: 93, 1987.

20. Lanks, K. W., and Li, P. W. Fnd products of glucose and glutamine metabolism by cultured cell lines. J. Cell. Physiol. 135: 151, 1988.

21. Reitzer, L. J., Wice, B. M., and Kennell, D. Evidence that glutamine, not sugar, is the major energy source for cultured HeLa cells. $J$. Biol. Chem. 254: 2669, 1979.

22. Ardawi, M. S. M. Glutamine and glucose metabolism in human peripheral lymphocytes. Metabolism 37: 99, 1988.

23. Stanley, P. E., and Williams, S. G. Use of the liquid scintillation spectrometer for determining adenosine triphosphate by the luciferase enzyme. Anal. Biochem. 29: 281, 1969.

24. Hyslop, P. A., and Sklar, L. A. A quantitative fuorometric assay for the determination of oxidant production of polymorphonuclear leukocytes: Its use in the simultaneous fluorometric assay of cellular activation processes. Anal. Biochem. 141: 280, 1984.

25. Askanazi, J., Carpentier, Y. A., Michelsen, C. B., Elwyn, D. H., Furst, P., Kantrowitz, I. R., Gump, F. E., and Kinney, J. M. Muscle and plasma amino acids following injury: Influence of intercurrent infection. Ann. Surg. 192: 78, 1980. 